\title{
The effect of rare earth elements on phosphorus leaching in intact soil columns
}

\author{
C.D. Church, A.R. Buda, P.J.A. Kleinman, and L.S. Saporito
}

\begin{abstract}
Phosphorus (P) has been linked to eutrophication in surface waters because it is a limiting nutrient for algal growth, and recent studies have shown that $\mathrm{P}$ transport through subsurface flow is of growing concern. In this study we amended dairy and poultry manures with lanthanum $(\mathrm{La})$ and ytterbium $(\mathrm{Yb})$ chlorides to assess the efficacy of using rare earth element (REE) chloride amendments in reducing $\mathrm{P}$ leaching through intact soil columns and to determine the major pathways of applied P leaching. Significant reductions in dissolved $\mathrm{P}$ (DP; $56 \%$ to $64 \%$ ), particulate P (PP; $22 \%$ to $36 \%$ ), and total P (TP; $41 \%$ to $51 \%$ ) in leachate were seen when dairy manure was amended with REE-chlorides, but no significant reductions in these $\mathrm{P}$ fractions were seen in amended poultry litter. Differences in P leaching losses between the two REE-amended manures were likely due to better mixing and dissolution of the REE-chlorides and better precipitation of an insoluble particulate REE-phosphate salt in the liquid manures prior to being applied.Very little vertical transport of REEs was observed in soil leachate over repeated events. Elevated concentrations of REEs along soil macropores at depths greater than $15 \mathrm{~cm}$ (5.9 in) suggest the importance of this pathway. However, due to the extremely low concentrations of REEs found at depth and the much higher values of soil P, the ability to "label" the manures with REEs to track P through macropores in the soil was only suggestive and by no means conclusive. Results point to the efficacy of REE-chlorides in lowering $\mathrm{P}$ solubility in liquid manures but limited potential in tracking subsurface transport pathways of applied manure $\mathrm{P}$ in soils.
\end{abstract}

Key words: dairy manure-leaching-lysimeters-phosphorus-poultry litter-rare earth elements

\begin{abstract}
Once relegated as a marginal pathway of agricultural phosphorus (P) loss, leaching of $P$ through soils has increasingly been associated with some of the world's most prominent examples of eutrophication (Sharpley et al. 1994). From Lake Erie, to the Chesapeake Bay, to the Baltic Sea, P leaching through the profile of agricultural soils fertilized with either mineral or manure sources of $\mathrm{P}$ has been tied to surface water $\mathrm{P}$ loadings. An increase in the enrichment of ground waters with $\mathrm{P}$ has been attributed to surface applications of $\mathrm{P}$ in agriculture (Holman et al. 2008; Domagalski et al. 2011). Increasingly, demand has grown for techniques that elucidate the mechanisms of subsurface agricultural P losses (Djodjic et al. 2002) and opportunities for controlling these losses (Buda et al. 2012).

It is widely recognized that subsurface $\mathrm{P}$
\end{abstract} transfers occur through macropore pathways
(Polyakov et al. 2004) and in the fate of $\mathrm{P}$ from applied sources (Buda et al. 2010). These Group IIIA elements, including ytterbium $(\mathrm{Yb})$ and lanthanum (La), typically exist as trivalent cations (Loell et al. 2011) and readily bind with orthophosphate to form insoluble salts (Firsching and Brune 1991). Several recent studies have evaluated the effect of REEs on applied P losses in surface runoff (Buda et al. 2010; Wang et al. 2011a, 2012). These studies all quantified reductions in dissolved $\mathrm{P}$ losses with surface application of manure $(>50 \%)$ and generally reported strong correlations between total $\mathrm{P}$ and REE losses in runoff. Indeed, Buda et al. (2010) posited that blending manures with REEs holds promise as a P-labeling mechanism for studying applied $\mathrm{P}$ losses from manure-amended soils due to the aforementioned affinity of REEs to dissolved P fractions in manure.

A logical extension of the research on REEs and $\mathrm{P}$ in surface runoff is the application of REEs to the study of $\mathrm{P}$ leaching from soils. To date, two studies have examined the effect of adding REEs to soils on P leaching (Lang et al. 2010; Wang et al. 2011b), but both of these studies employed packed column experiments that inherently minimized P leaching potential due to the destruction of intact macropores. Not surprisingly, very little effect of REE addition on vertical leaching of $\mathrm{P}$ was observed. In one study, concentrations of $\mathrm{P}$ in leachate were very low $\left(<0.25 \mathrm{mg} \mathrm{L}^{-1}[\mathrm{ppm}]\right.$; Liang et al. 2010), while in the other study, total $\mathrm{P}$ losses in leachate accounted for $4 \%$ to $8 \%$ of surface applied P (Wang et al. 2011b). In both studies, concentrations of REEs and $\mathrm{P}$ in soils were similar to background levels at depths greater than $6 \mathrm{~cm}$ (2.4 in), owing to the limited potential of matrix flow pathways to leach these elements.

In this study, we used two REE-chlorides to study the fate and transport of $\mathrm{P}$ in intact soil columns, which included soils from sites where $\mathrm{P}$ leaching losses are of primary concern. Our objectives were to (1) evaluate the effect of amending manure with

Clinton D. Church is a research chemist, Anthony $\mathbf{R}$. Buda is a research hydrologist, Peter J.A. Kleinman is a research leader, and Lou S. Saporito is a research support scientist at the USDA Agricultural Research Services (ARS), Pasture Systems and Watershed Management Research Unit, University Park, Pennsylvania. 
REE-chlorides on P leaching and (2) examine the utility of REEs in tracing particulate $\mathrm{P}$ in leachate and in characterizing preferential pathways of P movement. Specifically, we conducted leaching experiments on three soils, two upland soils where dairy manure is typically applied and one coastal plain soil where poultry litter is the major manure amendment.

\section{Materials and Methods}

Column Leaching Experiments. To assess $\mathrm{P}$ and REE leaching related to manure and lanthanide application method, soils were selected to represent dominant agricultural series in dairy (Hagerstown and Honeoye) and poultry (Matapeake) producing regions of the northeastern United States. Forty-five $30 \mathrm{~cm}$ (11.8 in) deep intact soil columns were collected from three locations in the northeast United States: 15 from a Hagerstown soil unit (fine, mixed, semiactive, mesic Typic Hapludalf) in Pennsylvania, 15 from a Honeoye soil unit (fine-loamy, mixed, active, mesic Glossic Hapludalf) in New York, and 15 from a Matapeake soil unit (fine-silty, mixed, semiactive, mesic Typic Hapludults) on the eastern shore of Maryland (table 1). The Hagerstown and Honeoye soils provided a contrast in surface soil $\mathrm{pH}$. While both soils were derived from limestone parent materials, the pedogenically older Hagerstown soil is moderately acidic, whereas the younger Honeoye (derived from calcareous glacial till) represents alkaline conditions. In the case of the Matapeake columns, the surface soils possessed high concentrations of $\mathrm{P}$ (Mehlich-3 P averaged $384 \mathrm{mg} \mathrm{kg}^{-1}$ [ppm]) due to their past history of receiving poultry litter at rates often exceeding annual crop removal (Kleinman et al. 2007a).

Soil column tubes were inserted into the soil by hoisting a $2 \mathrm{Mg}(2.2 \mathrm{tn})$ weight up a $3 \mathrm{~m}(9.8 \mathrm{ft})$ tower and dropping it repeatedly onto a $30 \mathrm{~cm}$ (11.8 in) diameter $\times 30$ $\mathrm{cm}$ (11.8 in) tall schedule 80 PVC cylinder (Kleinman et al. 2005). The top of the column tube was pushed to within $2 \mathrm{~cm}(0.08$ in) of the soil surface to avoid compaction and provide head space for irrigation water. Removal of the intact columns was executed by digging a trench alongside of the cylinder and tilting it back to snap interface between the encased and subsurface soil before lifting it out of the ground.

The columns were inverted, the bottom surface was leveled and voids between ped faces were filled with washed sand (figure
1). A nylon filter and $30 \mathrm{~cm}$ (11.8 in) diameter PVC disc, perforated with $60,0.2 \mathrm{~cm}$ (0.08 in) holes was fastened to the bottom of the column with silicone caulk and stainless steel screws. A PVC cap was slipped over the perforated disk and column and sealed with silicone caulk to prevent leakage. Soil columns were then transported upright to a temperature controlled, insulated building. A hole was drilled into the bottom of the cap and tapped, and a $1 \mathrm{~cm}$ (0.4 in) PVC nipple was screwed into the threaded hole to serve as a port for leachate collection. This design ensured that columns were freely draining so as to avoid reducing conditions during the course of the leaching experiments.

Five different treatments were assigned to each soil series grouping so that each of the treatments was replicated three times for each soil (15 lysimeters per soil type). The five treatments were as follows: (1) an unamended soil, (2) a manure only application, (3) an REE only application, (4) manure applied with a 1:1 molar ratio of REE to water extractable P (WEP), and (5) manure applied with a 2:1 molar ratio of REE to WEP. The REE salts were mixed with liquid dairy slurry and poultry litter immediately prior to their application.

Columns were irrigated with $2 \mathrm{~cm}(0.79$ in) of deionized water twice per week for four weeks to simulate natural rainfall rates corresponding roughly to average weekly rainfall depths at the study sites. In total, seven irrigations were applied to the columns-one irrigation before treatments were administered and six irrigations after application of manures and/or REEs. Leachate was collected, volumes were measured, and subsamples were portioned off 24 hours after the columns were irrigated.

Manures. Dairy manure (table 2) from lactating Friesian-style dairy cows (Bos taurus) was collected from a working dairy farm near Rock Springs, Pennsylvania, after agitating a liquid manure storage tank. This manure is representative of typical manures applied to the Hagerstown (Pennsylvania) and Honeoye (New York) soils. Poultry manure from a litter storage shed at a broiler chicken (Gallus domesticus L.) operation in Princess Anne, Maryland, was collected to represent typical manure applied to the Matapeake (Eastern Shore, Maryland) soils. Both the dairy slurry and poultry litter were stored at $4^{\circ} \mathrm{C}\left(39.2^{\circ} \mathrm{F}\right)$ in air-tight containers for approximately one week before being applied to soils at the maximum rate allowed by Pennsylvania law $\left(84,000 \mathrm{~L} \mathrm{ha}^{-1}[9,000\right.$ gal $\left.\mathrm{ac}^{-1}\right]$ ). The resultant total phosphorus (TP) application rate for dairy slurry was $49.7 \mathrm{~kg} \mathrm{ha}^{-1}\left(44.2 \mathrm{lb} \mathrm{ac}^{-1}\right)$. Poultry litter was applied at a matching rate of TP and resulted in an application rate of $3,634 \mathrm{~kg} \mathrm{ha}^{-1}(3,234$ $\mathrm{lb} \mathrm{ac}^{-1}$ ) (Beegle 2013).

Rare Earth Elements. REEs were mixed with the dairy slurry and the poultry litter immediately prior to application. REE chlorides were dried in an oven to drive off waters of hydration and kept in a desiccator prior to being weighed for these experiments. A mixture of $\mathrm{La}$ and $\mathrm{Yb}$ (50:50, molar basis) in manure was applied to select soils at 1:1 and 2:1 molar ratio of a total REE to manure WEP, resulting in $0.93 \mathrm{~g}(3.8 \mu \mathrm{mols})$ of lanthanum(III) chloride $\left(\mathrm{LaCl}_{3}\right)$ and $1.06 \mathrm{~g}(3.8$ $\mu$ mols) of ytterbium(III) chloride $\left(\mathrm{YbCl}_{3}\right)$ at the 1:1 REE:Manure WEP rate and $1.87 \mathrm{~g}$ (7.6 $\mu \mathrm{mols})$ of $\mathrm{LaCl}_{3}$ and $2.13 \mathrm{~g}(7.6 \mu \mathrm{mols})$ of $\mathrm{YbCl}_{3}$ at the 2:1 REE:Manure WEP rate for dairy manure. Because poultry litter had a much lower WEP, only $0.34 \mathrm{~g}(1.38 \mu \mathrm{mols})$ of $\mathrm{LaCl}_{3}$ and $0.39 \mathrm{~g}(1.38 \mu \mathrm{mols})$ of $\mathrm{YbCl}_{3}$ at the 1:1 REE:Manure WEP rate and $0.68 \mathrm{~g}$ (1.38 $\mu$ mols $)$ of $\mathrm{LaCl}_{3}$ and $0.78 \mathrm{~g}(1.38 \mu \mathrm{mols})$ of $\mathrm{YbCl}_{3}$ at the 2:1 REE:Manure WEP rate were needed. This application rate of REE/ manure mixture to soils resulted in a soil REE loading that was at least five times the background level of each of the individual background levels in the soils. All treatments were applied 24 hours before irrigation.

Postleaching Soils Collection. After the final leaching of the column, the soils were dyed by flooding the soils with $2 \mathrm{~cm}$ (0.78 in) of $1 \%$ FD\&C Blue Dye No. 1 per Kleinman et al. (2005). After allowing the columns to drain for one hour, the top 0 to $1 \mathrm{~cm}$ (0.39 in) and 1 to $3 \mathrm{~cm}$ (0.39 to 1.2 in) of the soils were carefully excavated and saved for later analysis. The columns were then inverted and carefully excavated from the bottom to expose the $30 \mathrm{~cm}$ (11.8 in) and $15 \mathrm{~cm}$ (5.9 in) depths. Samples of the blue-stained soil from the center of macropores as well as the unstained matrix soil at each depth were collected and saved for later extraction and analysis.

Laboratory Analyses. Soil samples were air dried and sieved (2 mm [0.079 in]) prior to extraction or digestion. Total concentrations of $\mathrm{P}, \mathrm{La}$, and $\mathrm{Yb}$ in soil were determined by digesting $0.5 \mathrm{~g}(0.018 \mathrm{oz})$ soil in $2.5 \mathrm{~mL}$ $(0.084 \mathrm{oz})$ aqua regia $(25 \% 12 \mathrm{M}$ nitric acid 


\section{Table 1}

Properties of soils used in this study.

\begin{tabular}{|c|c|c|c|c|c|c|}
\hline \multirow[b]{2}{*}{ Soil } & \multirow{2}{*}{$\begin{array}{l}\text { Mehlich-3 } \\
\text { P }\left(\mathrm{mg} \mathrm{kg}^{-1}\right)\end{array}$} & \multirow{2}{*}{$\begin{array}{l}\text { Water } \\
\text { extractable } \\
\mathbf{P}\left(\mathrm{mg} \mathrm{kg}^{-1}\right)\end{array}$} & \multirow[b]{2}{*}{ pH (1:1 water) } & \multicolumn{3}{|c|}{ Particle size distribution (\%)* } \\
\hline & & & & Sand & Silt & Clay \\
\hline Hagerstown & 62.4 & 3.0 & 5.7 & 30 & 35 & 35 \\
\hline Honeoye & 21.0 & 2.5 & 7.7 & 38 & 34 & 28 \\
\hline Matapeake & 384.2 & 32.3 & 6.3 & 27 & 53 & 23 \\
\hline
\end{tabular}

Note: $\mathrm{P}=$ phosphorus.

*Particle size distribution based on 0 to $15 \mathrm{~cm}$ sample.

\section{Figure 1}

Photographs of the (a) drop hammer, (b) excavation of intact cores, (c) inverted core with soil prepped for closure, (d) sand used to create a smooth surface, (e) perforated plate with construction fabric used to hold sand and column in place, (f) water tight coupling used to secure cap, (g) a fully prepared column ready for transport to the laboratory, (h) lysimeters installed at the laboratory during the leaching experiments, and (i) schematic of lysimeters components.

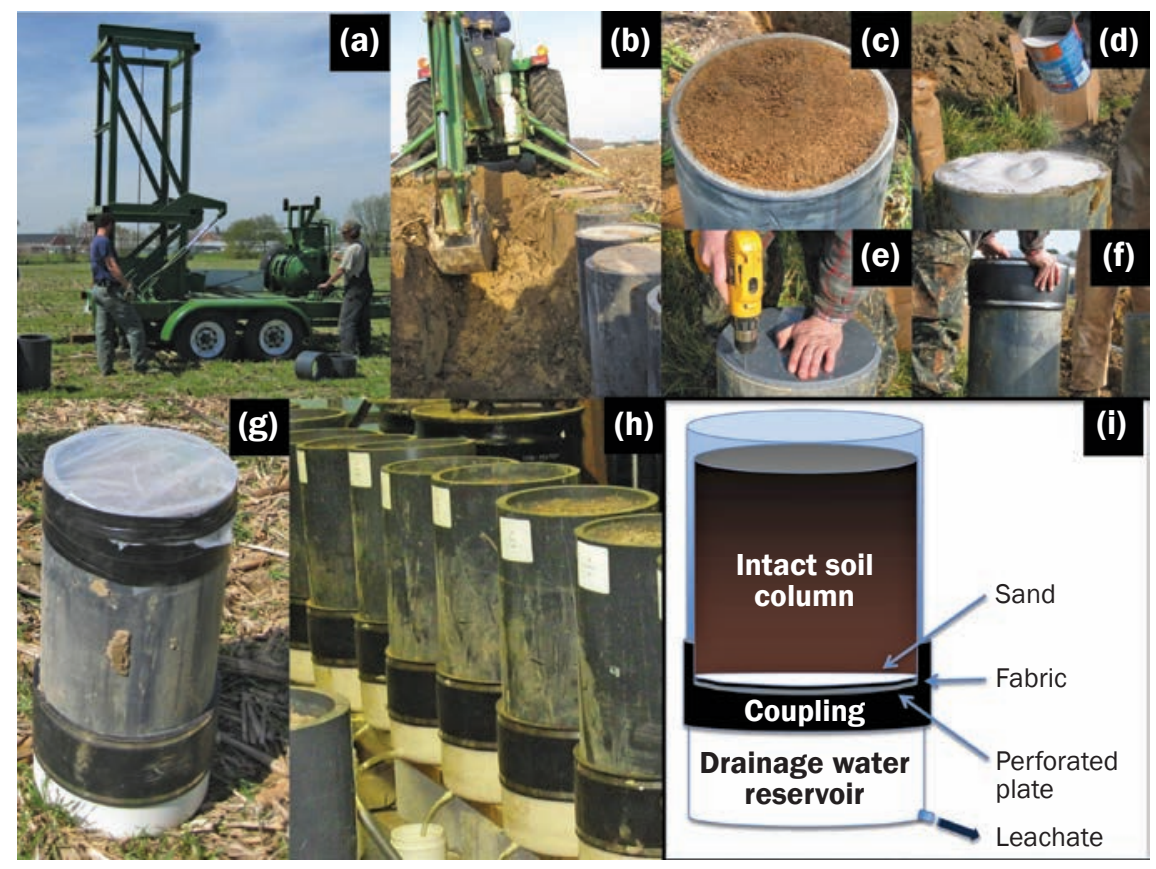

Table 2

Properties of manures used in this study.

\begin{tabular}{lcclll}
\hline Manure type & Solids & $\begin{array}{l}\text { Total } \mathbf{P} \\
(\mathbf{g ~ k g}\end{array}$ & $\begin{array}{l}\text { Total La } \\
\left(\mathbf{g ~ k g}^{-\mathbf{1}} \mathbf{)}\right.\end{array}$ & $\begin{array}{l}\text { Total } \mathbf{~ Y b} \\
\left(\mathbf{g ~ k g}^{-\mathbf{1}}\right)\end{array}$ & $\begin{array}{l}\text { Water extractable } \\
\mathbf{P}\left(\mathbf{g ~ k g}^{-\mathbf{1}}\right)\end{array}$ \\
\hline Dairy manure & 7.6 & 7.63 & 0.03 & 0.0001 & 5 \\
Poultry litter & 68.5 & 20.23 & 0.04 & 0.0003 & 4.7 \\
\hline
\end{tabular}

Note: Nutrients reported on a dry weight basis. $\mathrm{La}=$ lanthanum. $\mathrm{Yb}=$ ytterbium. $\mathrm{P}=$ phosphorus.

$\left[\mathrm{HNO}_{3}\right]+75 \% 12 \mathrm{M}$ hydrochloric acid $[\mathrm{HCl}])$ for two hours at $95^{\circ} \mathrm{C} \pm 5^{\circ} \mathrm{C}\left(203^{\circ} \mathrm{F}\right.$ $\pm 9^{\circ} \mathrm{F}$ ), and diluted $25: 1$ prior to being filtered through a Whatman No 1. paper filter. Mehlich-3 determinations were made by shaking $2 \mathrm{~g}(0.9 \mathrm{oz})$ of soil in $20 \mathrm{ml}(0.85$ $\mathrm{oz}$ ) of Mehlich-3 solution (0.2 $\mathrm{M}$ acetic acid $\left[\mathrm{CH}_{3} \mathrm{COOH}\right]+0.25 \mathrm{M}$ ammonium nitrate $\left[\mathrm{NH}_{4} \mathrm{NO}_{3}\right]+0.015 \mathrm{M}$ ammonium fluoride $\left[\mathrm{NH}_{4} \mathrm{~F}\right]+0.013 \mathrm{M} \mathrm{HNO}_{3}+0.001$ $\mathrm{M}$ ethylenediaminetetraacetic acid [EDTA]) for five minutes prior to being neutralized and filtered (through a Whatman No. 1 filter). WEP, La, and $\mathrm{Yb}$ were measured by shaking $2 \mathrm{~g}(0.07 \mathrm{oz})$ of soil in $20 \mathrm{~mL}(0.68 \mathrm{oz})$ of distilled water for one hour and filtering the supernatant through a Whatman No. 1 paper filter. All digests and extractions were analyzed by inductively coupled argon plasma optical emission spectrophotometer (ICP-OES). Soil $\mathrm{pH}$ was determined by mixing air-dried soil with distilled water (1:1). Recalcitrant $\mathrm{P}$ and REEs were calculated as the total minus the water extractable portion.

Total concentrations of $\mathrm{P}, \mathrm{La}$, and $\mathrm{Yb}$ in manures were determined by digesting $0.25 \mathrm{~g}(0.09 \mathrm{oz})$ manure in $5 \mathrm{ml}(0.17 \mathrm{oz})$ aqua regia $\left(25 \% 12 \mathrm{M} \mathrm{HNO}_{3}+75 \% 12 \mathrm{M}\right.$ $\mathrm{HCl})$ for two hours at $95^{\circ} \mathrm{C} \pm 5^{\circ} \mathrm{C}\left(203^{\circ} \mathrm{F}\right.$ $\pm 9^{\circ} \mathrm{F}$ ), and diluted $25: 1$ prior to being filtered (Whatman No. 1 paper filter). WEP, $\mathrm{La}$, and $\mathrm{Yb}$ in manures were measured by agitating $1 \mathrm{~g}(0.36 \mathrm{oz})$ of manure in $100 \mathrm{ml}$ (3.4 oz) of distilled water for one hour, and filtering the supernatant through a Whatman No. 1 paper filter (Kleinman et al. 2007b). All digests and extractions were analyzed by ICP-OES. Manures were dried at $70^{\circ} \mathrm{C}$ $\left(158^{\circ} \mathrm{F}\right)$ for 48 hours, and their dry matter content was determined gravimetrically.

Leachate waters were filtered $(0.45 \mu \mathrm{m}$ [0.000018 in]) for determination of dissolved constituents (DP, DLa, and DYb). TP digests were prepared by adding $10 \mathrm{ml}(0.34 \mathrm{oz})$ aqua regia $\left(25 \% 12 \mathrm{M} \mathrm{HNO}_{3}+75 \% 12 \mathrm{M}\right.$ $\mathrm{HCl})$ to $2.5 \mathrm{ml}(0.085 \mathrm{oz})$ of an unfiltered portion of leachate water and digesting at $95^{\circ} \mathrm{C} \pm 5^{\circ} \mathrm{C}\left(203^{\circ} \mathrm{F} \pm 9^{\circ} \mathrm{F}\right)$ for two hours. Digested water was brought to a $25 \mathrm{ml}(0.85$ oz.) final volume and filtered (Whatman No. 1 paper filter). Leachate waters and digestions were analyzed for P, La, and Yb by ICP-OES.

Data Analysis. Prior to analysis by conventional parametric statistics, data were tested for normality and homogeneity of variance to ensure compliance with Gaussian distribution requirements. Pearson's correlation and differences among treatments were evaluated using Igor Pro V. 5.0 (Wavemetrics Inc., Lake Oswego, Oregon) by analysis of variance (one- and two-way ANOVA) and Welch's $t$-test (Welch 1947). When required due to skewing of data, the Brown and Forsythe test (Brown and Forsythe 1974) was used to calculate the $F$ statistic resulting from an ordinary one-way analysis of variance on the absolute deviations from the median. Differences among treatments were evaluated by general linear model, and individual 
treatment means grouped by Neuman Keul's pair-wise comparison as its sequential testing method was more discriminatory than Tukey's test (Keuls 1952). Statistical results were considered significant at $\alpha=0.05$.

\section{Results and Discussion}

Cumulative P losses (table 3) in the control lysimeters revealed that while the ratio of dissolved P (DP) to TP was similar for Hagerstown and Honeoye soils $38 \%$ and $41 \%$, respectively), $95 \%$ of $\mathrm{TP}$ occurred as DP in the Matapeake soil. As reported by Han et al. (2015), this is likely an effect of soil structure, as the Honeoye and Hagerstown soils have numerous macropores whereby solids may be transported, while the Matapeake soils do not.

Effects of Rare Earth Element Amendment on Dissolved Phosphorus Concentrations in Leachate. Overall patterns in leaching of DP were similar across all three soils (figure 2). Concentrations of DP in leachate spiked after the first leaching event when manure was applied and then declined with subsequent leaching events (figure 2) except in the Matapeake soils where concentrations only increased slightly in event 2 . This general pattern of "first flush" leaching of DP in the initial events after manure is applied followed by decreases in concentration for subsequent events is typical for DP, both with and without amendments to control its movement (Kleinman et al. 2005; Kibet et al. 2013; Liang et al. 2012; Wang et al. 2011b).

Flow-weighted mean peak DP concentrations for the manure-only amended soils were $1.9 \mathrm{mg} \mathrm{L}^{-1}$ for the Hagerstown soils, 2 $\mathrm{mg} \mathrm{L}^{-1}$ for the Honeoye soils, and $5.3 \mathrm{mg} \mathrm{L}^{-1}$ for the Matapeake soils. These concentrations were comparable to the values reported in similar studies, except for the Matapeake soils, where peak DP concentrations were as high as $15 \mathrm{mg} \mathrm{L}^{-1}$, likely reflecting the higher manure application rate used in those studies (Kleinman et al. 2005; Kibet et al. 2013).

Leachate concentrations of DP seen in REE amended Hagerstown and Honeoye soils $\left(0.62 \mathrm{mg} \mathrm{L}^{-1}\right.$ and $0.86 \mathrm{mg} \mathrm{L}^{-1}$ for Hagerstown and Honeoye, respectively) were at the higher end of the range of DP leachates reported by an earlier REE amendment study $\left(0.18 \mathrm{mg} \mathrm{L}^{-1}\right.$ to $0.79 \mathrm{mg}$ $\mathrm{L}^{-1}$; Wang et al. 2011b), but considerably higher than another study $\left(0.15 \mathrm{mg} \mathrm{L}^{-1}\right.$ to $0.20 \mathrm{mg} \mathrm{L}^{-1}$; Liang et al. 2012) using REEs as a manure amendment. This is possibly due to their use of soils that were relatively low in $\mathrm{P}$ compared to the Hagerstown and Honeoye soils used in this study, and so, served as sinks for DP through sorption. By contrast, the mean peak DP concentration for the first flush Matapeake REE amended soils was even greater, at 6.5 times higher than the mean DP concentrations from the Honeoye and Hagerstown soils. By the fifth leaching event, DP concentrations across all treatments appeared similar to the controls.

Effects of Rare Earth Element Amendments on Phosphorus Leaching Losses. Overall patterns in $\mathrm{P}$ loads in leachate ( $\mu$ mols) were similar between the Hagerstown and Honeoye soils, and very different for the Matapeake soils. Cumulative P losses showed clear evidence that REE amendments lowered all fractions of $\mathrm{P}$ (DP, particulate $\mathrm{P}[\mathrm{PP}]$, and $\mathrm{TP}$ ) in leachate from dairy manureamended Hagerstown and Honeoye soils (figure 3). Total DP loss at the end of the six leaching events reflect this also (table 3 ), with manure-only treatments being significantly higher in both soils than the manure plus REE amended soils. Significant reductions in DP (56\% and 64\%), PP (22\% and $36 \%)$, and TP (41\% and 51\%) compared to the controls were seen for the Honeoye and Hagerstown soils, respectively. Furthermore, for DP, both the 1:1 and 2:1 REE amendments produced statistically similar results to the unamended treatments for both soils, suggesting that a 1:1 molar treatment is sufficient. PP and TP were reduced to unamended levels in both soils also, though those levels were achieved with the 1:1 REE amendment for Hagerstown soils, while the 2:1 treatment was required for Honeoye soils. There did not seem to be an impact of REE treatment on legacy soil P in either the Hagerstown or Honeoye soils as leaching losses of DP, PP, and TP in the REE amended treatments were statistically similar to losses in the unamended soils. Conversely, in the Matapeake soils, there were no statistical differences in any $\mathrm{P}$ losses between treatments, indicating that the REEs were ineffective at reducing $\mathrm{P}$ losses from poultry litter applied to Matapeake soils.

There are three possible explanations for the contrast seen between soils receiving dairy manure and those receiving poultry litter. The first possibility is that while REE amendments remove all three forms of $\mathrm{P}$ from leachate, they are much more effective in liquid manures compared to dry manures, such as poultry litter. This same effect was also seen in an earlier runoff study (Buda et al. 2010) and was attributed to better mixing of REEs with the manure prior to application. A more likely explanation may be due to the timing of when the REEs become soluble. In the case of the dairy manure, the REEs from the REE-chloride were in a soluble form while still in intimate contact with soluble $\mathrm{P}$ in the dairy manures. Thus, they likely formed an insoluble REE-phosphate salt prior to being applied to the soils. In the case of the poultry litter, REE chlorides were applied dry to the soil along with the dry litter and became soluble only with the first irrigation event. A third possible explanation for the lack of significant differences seen between treatments in the Matapeake soils may have been due to elevated legacy P levels, which were an order of magnitude greater than those measured in Hagerstown and Honeoye soils (table 1). In this case, potential reductions of DP leaching by applied REEs were likely masked by high legacy P concentrations in the Matapeake soils.

Cumulative Losses of Lanthanum and Ytterbium in Leachate. Cumulative losses of REEs over the six leaching events (table 3) were less than $0.1 \%$ of the total REEs applied to all soils and few significant differences were seen in REE losses. The extremely low recovery of REEs in leachate, along with the increased variability inherently found in REE concentrations near detection limits, likely accounts for much of observed lack of statistical discrimination between treatments for the REE losses in leachate. Significant differences that were found indicated that there was an excess of REEs in the REE only and REE 2:1 treatments in the Honeoye soils. Losses of REEs in leachate were not reported in two previous studies of leaching following REE amendment of manures (Liang et al. 2012; Wang et al. 2011b), but the REE concentrations seen in those studies were higher than those seen in the current study. This is likely because the higher ratio of REEs:DP used in those studies resulted in greater REE losses, such as those observed for the REE only and 2:1 treatments for the Honeoye soils. Numerically, though usually not statistically different, in all cases where manures and REEs were mixed wet, particulate REE losses tended to be a greater fraction of total REE losses than were dissolved REEs in the Hagerstown and Honeoye soils, while the opposite was true in the Matapeake soils, suggesting that REE association with DP 
Table 3

Mean cumulative losses of phosphorus (P) and rare earth elements (REE) in leachate after six leaching events.

\begin{tabular}{|c|c|c|c|c|c|c|c|c|c|}
\hline \multirow[b]{2}{*}{ Treatment } & \multirow[b]{2}{*}{ TP } & \multirow[b]{2}{*}{ PP } & \multirow[b]{2}{*}{ DP } & \multicolumn{6}{|c|}{ REE ( $\mu$ mols) } \\
\hline & & & & TLa & PLa & DLa & TYb & PYb & DYb \\
\hline \multicolumn{10}{|l|}{ Hagerstown soil } \\
\hline Control & $170 a$ & $106 \mathrm{bc}$ & $64 a b$ & $0.51 a$ & $0.087 a$ & $0.62 a$ & $0.085 a$ & $0.085 a$ & $\mathrm{BDL}$ \\
\hline REE only & $150 a$ & $95 c$ & $58 b$ & $8.7 a$ & $0.46 a$ & 8.3a & $8.5 a$ & $2.8 a$ & $5.6 a$ \\
\hline Manure only & $470 b$ & $212 a$ & $250 c$ & $1.4 a$ & $\mathrm{BDL}$ & $1.8 a$ & $0.092 a$ & $0.042 a$ & $0.33 a$ \\
\hline Manure 1:1 & $290 a$ & $162 a b$ & $120 a$ & $3.6 a$ & $1.2 a$ & $2.3 a$ & $2.7 a$ & $1.6 a$ & $1.1 a$ \\
\hline Manure 2:1 & $230 a$ & $135 a c$ & $90 a b$ & $9.4 a$ & $4.8 a$ & $4.5 a$ & $3.9 a$ & $2.9 a$ & $1.0 a$ \\
\hline \multicolumn{10}{|l|}{ Honeoye soil } \\
\hline Control & $170 c$ & $101 a$ & $69 a$ & $0.16 a$ & $\mathrm{BDL}$ & $0.85 a$ & $0.13 a b$ & 0.090a & $\mathrm{BDL}$ \\
\hline REE only & $176 c$ & $95 a$ & $81 a$ & $6.3 c$ & $1.4 a$ & $4.9 a$ & $5.1 \mathrm{c}$ & $3.7 b$ & $1.4 \mathrm{~b}$ \\
\hline Manure only & $454 a$ & $200 b$ & $254 b$ & $0.16 a b$ & $\mathrm{BDL}$ & $2.0 a$ & $0.13 a$ & $0.072 a$ & $0.11 a$ \\
\hline Manure 1:1 & $356 a b$ & $219 b$ & $137 a$ & $3.1 \mathrm{~b}$ & $1.4 a$ & $2.4 a$ & $2.5 b$ & $2.0 a b$ & $0.45 a$ \\
\hline Manure 2:1 & $269 b c$ & 156ab & $113 a$ & $7.18 c$ & $2.2 a$ & $4.9 a$ & $5.8 \mathrm{c}$ & $4.3 b$ & $1.5 b$ \\
\hline \multicolumn{10}{|l|}{ Matapeake soil } \\
\hline Control & 1,001a & $35.7 a$ & $948 a$ & $2.3 a$ & $0.18 a$ & $2.2 a$ & $0.074 a$ & $0.006 a$ & $\mathrm{BDL}$ \\
\hline REE only & 1,006a & $35.1 a$ & $968 a$ & $3.1 \mathrm{a}$ & $0.16 a$ & $2.7 a$ & $0.18 a$ & $0.11 \mathrm{a}$ & $0.02 a$ \\
\hline Manure only & 1,096a & $36.6 a$ & $1,048 a$ & $3.7 a$ & $0.90 a$ & $2.8 a$ & $0.095 a$ & $0.12 a$ & $\mathrm{BDL}$ \\
\hline Manure 1:1 & $918 a$ & $60.4 a$ & $836 a$ & $7.4 a$ & $2.5 b$ & $5.0 a$ & $2.0 a$ & 0.64 & $1.2 \mathrm{a}$ \\
\hline Manure 2:1 & $1,024 a$ & $48.6 a$ & $948 a$ & $8.7 a$ & $3.7 \mathrm{~b}$ & $6.0 a$ & $3.1 a$ & $2.2 a$ & $2.0 a$ \\
\hline
\end{tabular}

Notes: TP $=$ total phosphorus. PP = particulate P. DP = dissolved P. TLa = total lanthanum (La). PLa = particulate La. DLa $=$ dissolved La. $\mathrm{TYb}=$ total ytterbium (Yb). PYb = particulate Yb. DYb = dissolved Yb. BDL= Below Detection Limit. Letters identify groupings per Neuman-Keuls pairwise comparison associated with each treatment.

and formation of an insoluble salt was the dominant reaction governing DP reductions in leachate.

Association between Phosphorus and Rave Earth Elements. To further explore whether an insoluble REE-phosphate salt was controlling, and thus "labeling" DP in manures, a correlation analysis was performed for both PP versus particulate REEs in leachate and for recalcitrant (either insoluble particles, consistent with the formation of REE-phosphate, or strongly sorbed to soils) $\mathrm{P}$ versus recalcitrant REEs in soils for both the 1:1 and 2:1 REE additions. While good correlations were found in both cases for the Hagerstown and Honeoye soils $(r>0.65$ for the particulate relationships and $r>0.80$ for the recalcitrant relationships), the relationships were largely dominated by event 2 . Therefore, while these relationships suggest an association between $\mathrm{P}$ and REEs, the results are not conclusive. While not dominated by a single event, the Matapeake soils showed a poor relationship $(r<0.07)$ for both the 1:1 and 2:1 REE additions, which was likely due to poor mixing, masking of effects by high legacy $\mathrm{P}$ concentrations, or because the manures and REEs were mixed dry prior to application.
Depth of Phosphorus, Lanthanum, and Ytterbium in Soil Matrix. Soil extractions of the top $3 \mathrm{~cm}$ (1.2 in) of the lysimeters revealed that almost all of the $\mathrm{P}, \mathrm{La}$, and $\mathrm{Yb}$ found in the soils was in a recalcitrant form, either as insoluble particles, consistent with the formation of REE-phosphate, or were strongly sorbed to soils (figures 4, 5, and 6). Not surprisingly, extractable $\mathrm{P}$ was found in all treatments due to historic manure application, but concentrations were highest in treatments receiving manure application except for the Matapeake soils. While it is possible that leaching in this experiment was able to remove all $\mathrm{P}$ from the applied manure, it is much more likely that high concentrations from legacy $\mathrm{P}$ were able to mask even the effects of adding manure to the soil. Also not surprisingly, the highest concentrations of extractable REEs were found in soils that were amended with REEs, although some (very low) concentrations were observed in the control and manure-only lysimeters as well, likely due to the soils and manures themselves having trace amounts of $\mathrm{La}$ and $\mathrm{Yb}$ (table 2).

Of the depths sampled, almost all $\mathrm{P}$ values were greater in the top $1 \mathrm{~cm}$ (0.39 in) as compared to the 1 to $3 \mathrm{~cm}$ (1.2 in) interval, except for the Matapeake soils, where WEP was equal at the two depths. Furthermore, the recalcitrant fraction of TP was higher at the lower depth for all the REE 1:1 treatment and the Hagerstown soils, where the 2:1 treatment was slightly higher at the surface and the REE only treatment was equal at the two depths. For REEs, all concentrations found in extractions were higher at the top $1 \mathrm{~cm}$. Two previous studies (Liang et al. 2010; Wang et al. 2011b) likewise found limited vertical transport of REEs, with almost all of the REEs applied found in the top 4 and $6 \mathrm{~cm}$ (1.5 and 2.3 in), respectively.

These findings are also consistent with the formation of an insoluble REE-phosphate salt since, once formed, it would be highly resistant to leaching through soils. More likely, the REE-phosphate would either be bound to soil particles or entrained in pore spaces at the very surface of the soil. Any likely transport to depth in the soil would necessarily take place through macropores.

Preferred Leaching Transport Pathways for Phosphorus, Lanthanum, and Ytterbium. The effect of macropore versus matrix transport pathways can be seen in the Hagerstown and Honeoye soils (figures 7 and 8). Unfortunately, as was also reported by Han et al. (2015), due to the nature of the Matapeake soils, no macropores were 
Figure 2

Total dissolved phosphorus (TDP) concentration by leaching event in (a) Hagerstown,

(b) Honeoye, and (c) Matapeake soils.

(a)

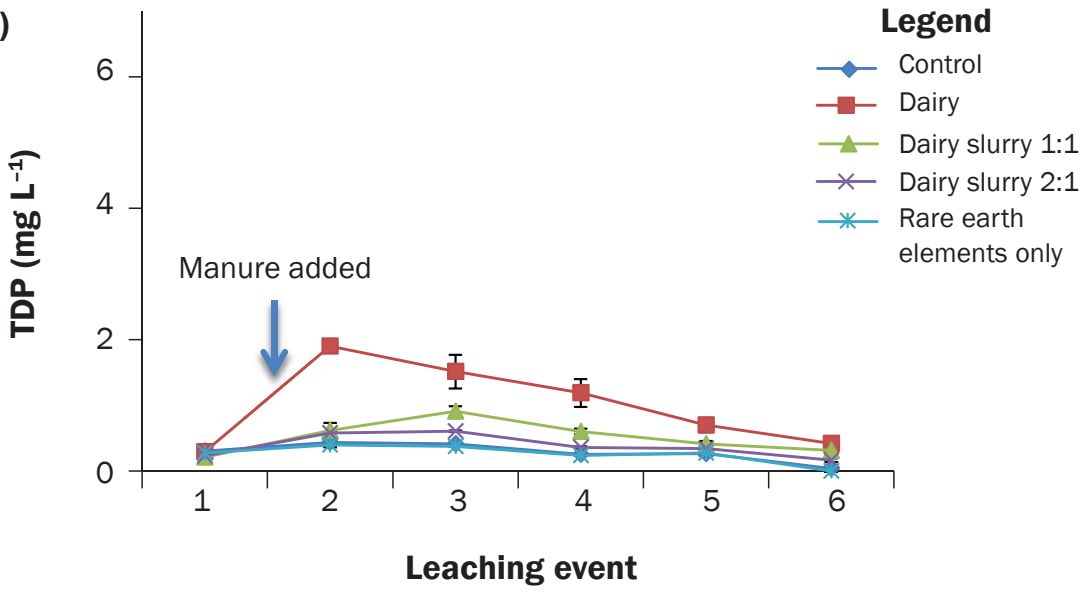

(b)

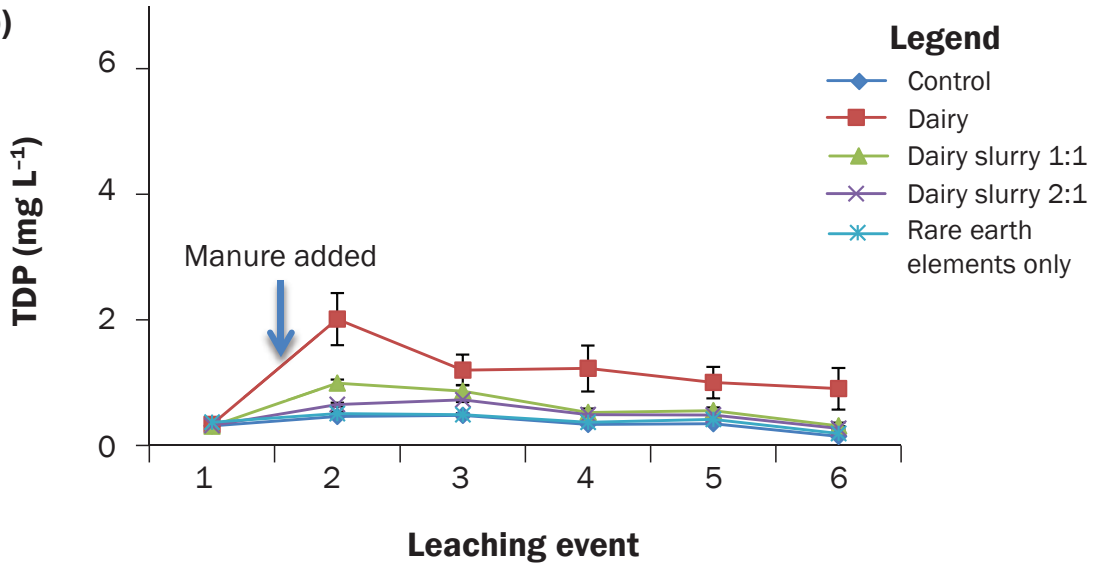

(c)

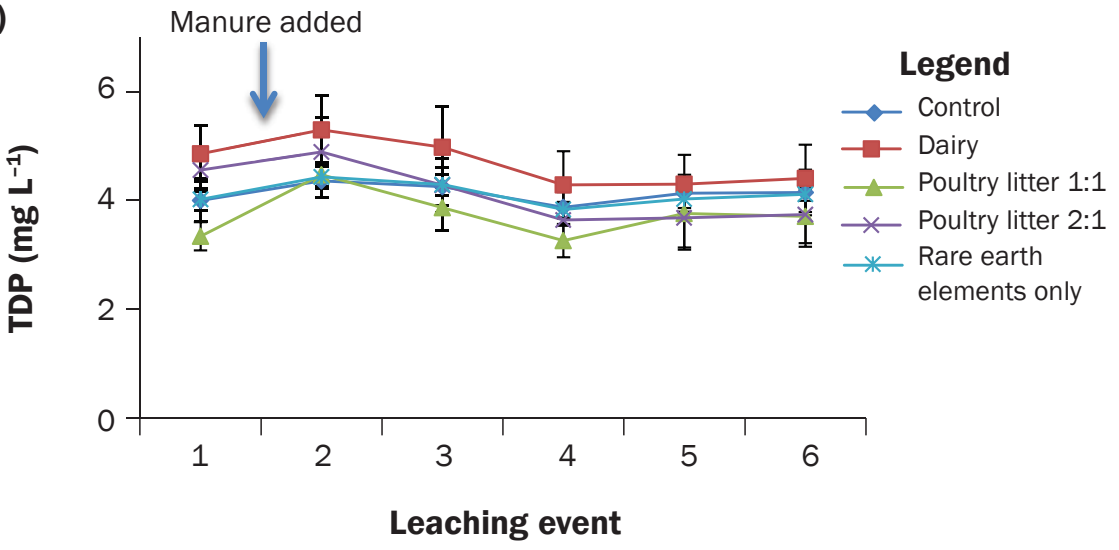

revealed by the staining technique used. With very few exceptions, when transport to depth of all forms of both $\mathrm{P}$ and REEs was observed, it did take place through macropores, as indicated by macropore concentrations at a given depth being greater than the corresponding matrix concentrations. This effect is clearly seen in REEs for the $15 \mathrm{~cm}$ (5.9 in) depth Honeoye and $30 \mathrm{~cm}$ (11.8 in) depth Hagerstown samples, where all forms of $\mathrm{La}$ and $\mathrm{Yb}$ were transported to depth through macropore flow while concentrations in most other samples reflected background concentrations or slight elevations in the macropores compared to the matrix. While $\mathrm{P}$ concentrations showed the same patterns in the lysimeters, the effect of macropore flow was not as obviously seen due to the higher background $\mathrm{P}$ concentrations. These findings again are further evidence that soluble REEs forming insoluble $\mathrm{P}$ salts are effective at controlling, and possibly even tracking $\mathrm{P}$ to depth in soil macropores.

\section{Summary and Conclusions}

Transforming DP in manures into PP by adding amendments either directly to manures or to soils is a management practice that has shown great potential for reducing DP leaching (Moore et al. 1994; Miller et al. 2011; Chardon et al. 2012). Chemically speaking, an ideal amendment for manures would rely on a mechanism that (1) showed rapid removal of DP and (2) provided for long-term fixation (an irreversible process) under potential environmental conditions. Three major mechanisms of DP removal by amendments are (1) adsorption, where DP is sorbed to the surface of the substrate and is a highly reversible mechanism; (2) absorption, where DP is incorporated into the structure of the matrix and is a less reversible mechanism; and (3) precipitation of an insoluble phosphate salt, a mechanism that is generally irreversible under environmental conditions. Of these three mechanisms, precipitation of an insoluble salt is preferred, since sorption processes can be reversible if concentrations in the adjoining water are lowered. What this means in the case of DP removal is that, by utilizing a sorption dominated mechanism of $\mathrm{P}$ removal, an immediate reduction of nonpoint source DP can be achieved. However, if $\mathrm{P}$ additions to soils are then ceased, that DP can then desorb from the substrate for years, becoming a source.

Most technologies currently used for the reduction of DP, with the exception of gypsum and soluble forms of aluminum ( $\mathrm{Al} ; \mathrm{Al}$ sulfate $\left[\mathrm{Al}_{2}\left(\mathrm{SO}_{4}\right)_{3}\right]$ or $\mathrm{Al}$ chloride $\left.\left[\mathrm{AlCl}_{3}\right]\right)$, rely on adsorption as the dominant mechanism for DP removal (Douglas et al. 2004; Buda et al. 2012; Leader et al. 2008). Above $\mathrm{pH} 5$, this even includes soluble $\mathrm{Al}$ amendments (Peake et al. 2002; Shober et al. 2006), since $\mathrm{Al}^{3+}$, which can form an insoluble salt with DP at low $\mathrm{pH}$ values, does not exist 


\section{Figure 3}

Cumulative losses of total dissolved phosphorus (TDP) in (a) Hagerstown, (b) Honeoye, and (c) Matapeake soils.
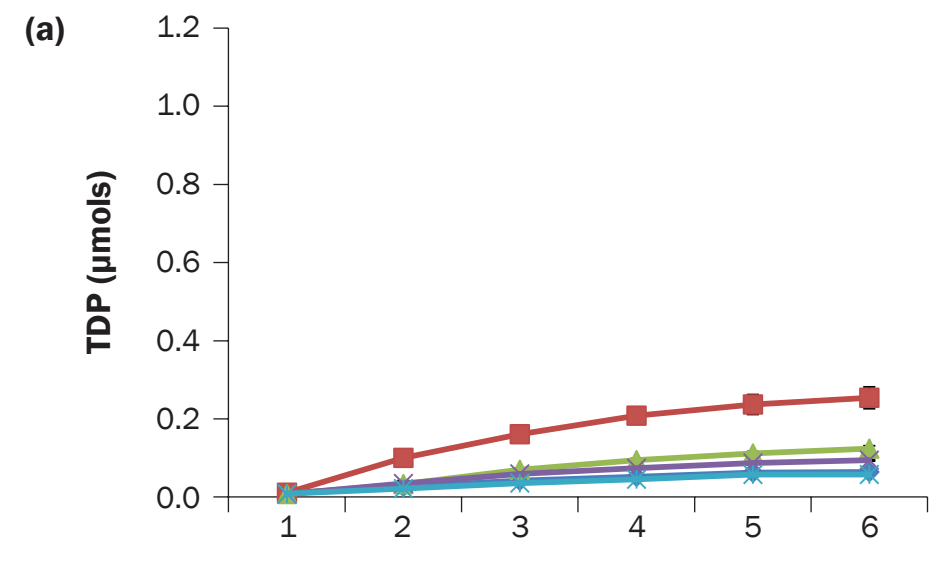

Leaching event

(b)

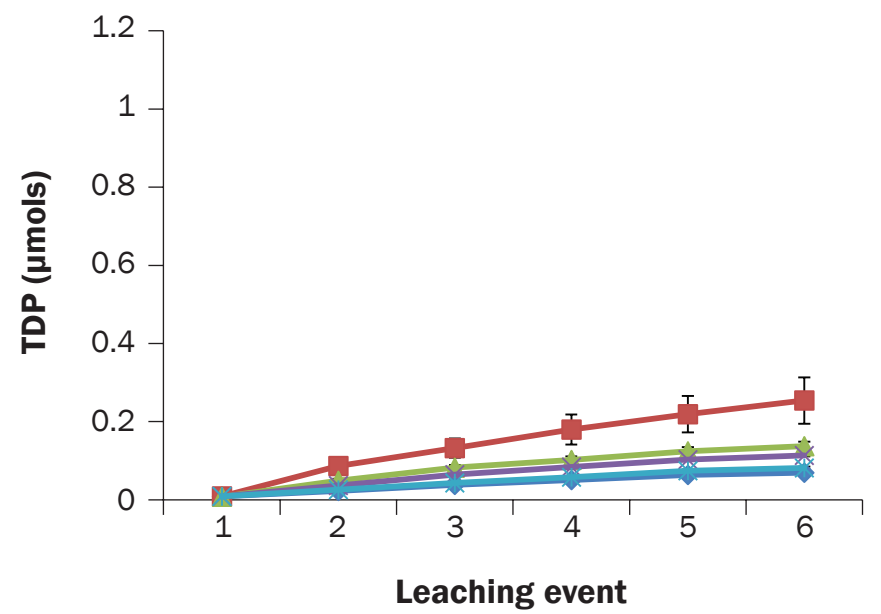

(c)

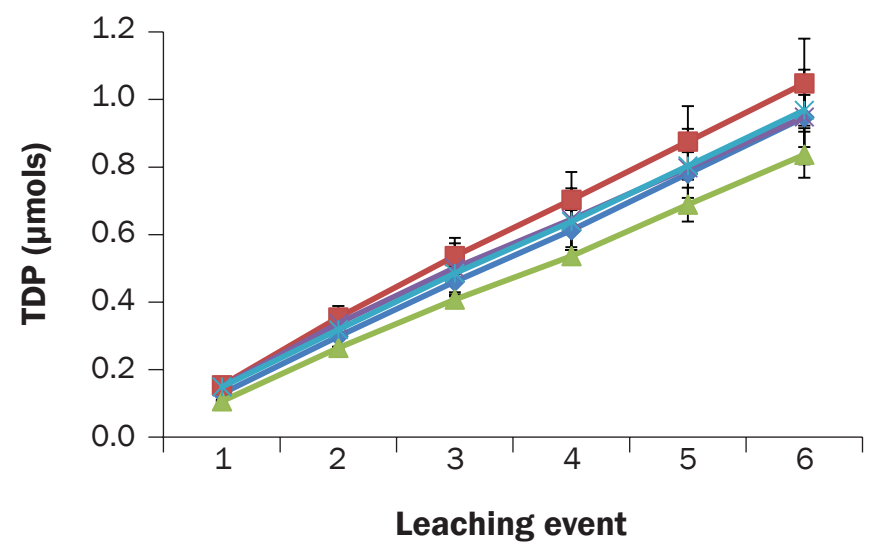

Legend

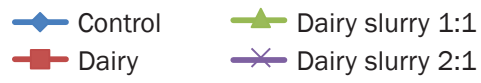

* Rare earth elements only

above pH 5 (Geological Survey of Japan 2005). Gypsum amendments do qualify as ideal amendments to soils or as permeable reactive barriers (PRBs) for intercepting DP in ditches and groundwater (Bryant et al. 2012), where they provide a long-term source of calcium $(2+)\left(\mathrm{Ca}^{2+}\right)$ that can react with chronic low concentrations of DP to form an insoluble salt (beta-tricalcium phosphate $[\beta-\mathrm{TCP}])$. However, since the solubility (potassium solubility product $\left[\mathrm{K}_{\mathrm{sp}}\right]$ $=3.14 \times 10^{-5}$ ) of gypsum (or any other Ca salt or mineral) is low (a desirable property in soils and PRBs) it does not provide high concentrations of $\mathrm{Ca}^{2+}$ ions rapidly enough to precipitate all of the DP found in high DP concentration manures before the DP can be removed by rainfall events, particularly since the dissolution of gypsum can only occur while it is wet, not while laying dry on soils between rainfall events.

Another difference between sorption and precipitation reactions is in their selectivity to similar, competing ions. Sorption reactions, particularly adsorption reactions, tend to be much less selective than precipitation reactions. This was illustrated in a recent controlled laboratory study where Ca phosphate was precipitated in preference to $\mathrm{Ca}$ arsenate when $\mathrm{Ca}$ was limiting (Neupane and Donahoe 2013). This nonselectivity of materials that use adsorption as their primary mechanism of DP removal could be an advantage in landscapes where arsenic containing compounds, such as roxarsone or nitarsone, have long been used or continue to be used in poultry feed (Garbarino et al. 2003; Church et al. 2010, 2011). It could also be a disadvantage in landscapes where other similar competing ions to DP could, over time, fill sorption sites, thus reducing the effectiveness of the amendment to sorb DP.

Our observations suggest that REEs are ideally suited for removing DP from manures. All 17 REEs form a stable 3+ cation in water at environmentally relevant $\mathrm{pH}$ values (Geological Survey of Japan 2005). Furthermore, unlike gypsum, if amended as a chloride salt, REEs are highly soluble in water (Mioduski et al. 2008). However, similar to $\mathrm{Ca}$, they form an insoluble $\left(\mathrm{K}_{\mathrm{sp}}\right.$ ranging from $10^{-25}$ to $10^{-27}$ ) salt with phosphate (Yoon et al. 2002; Kijkowska and LeGeros 2005), giving them the potential to form a permanent DP sink. While, chemically speaking, REEs do show much promise, their cost likely precludes their widespread 


\section{Figure 4}

Extractable (a, b, c) total phosphorus (TP), (d, e, f) lanthanum (La), and (g, h, i) ytterbium (Yb) in Hagerstown soils. REE refers to rare earth elements.

Total

(a)

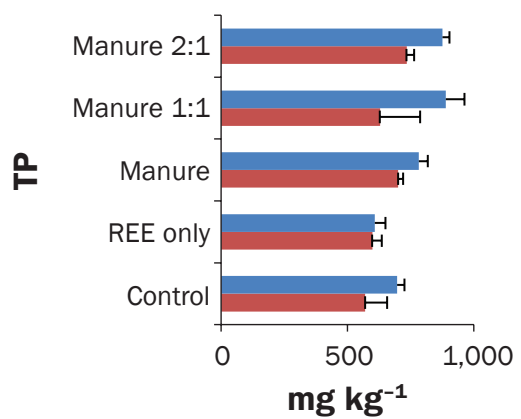

(d)

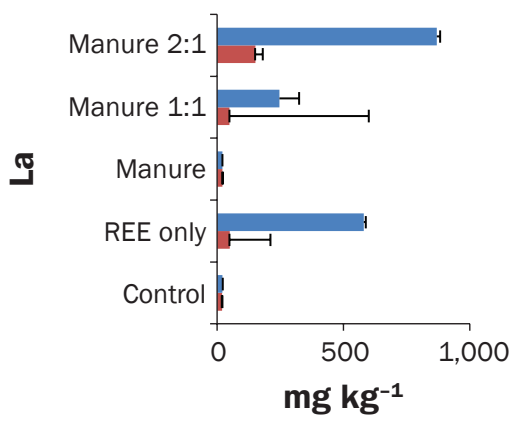

(g)

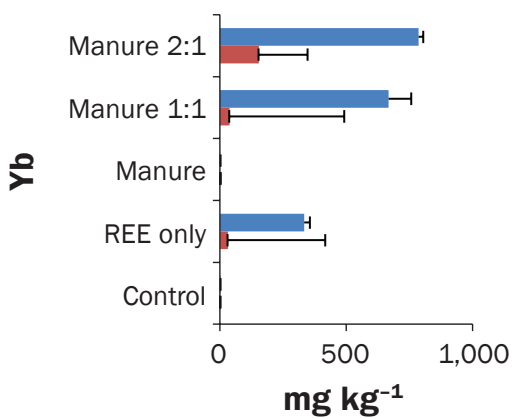

Legend

0 to $1 \mathrm{~cm}$

1 to $3 \mathrm{~cm}$

\section{"Recalcitrant"}

(b)

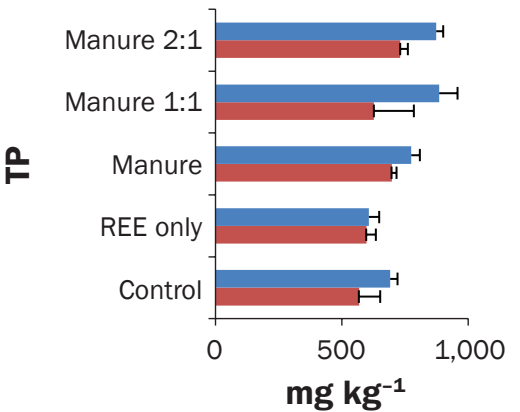

(e)

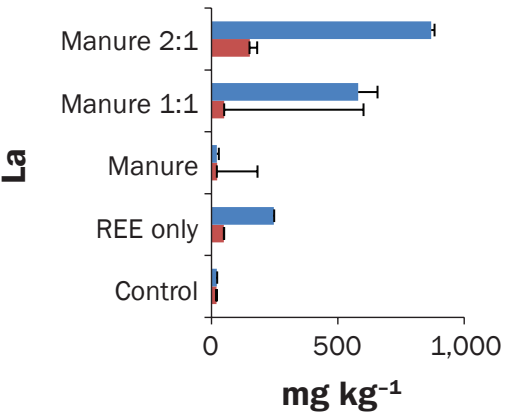

(h)

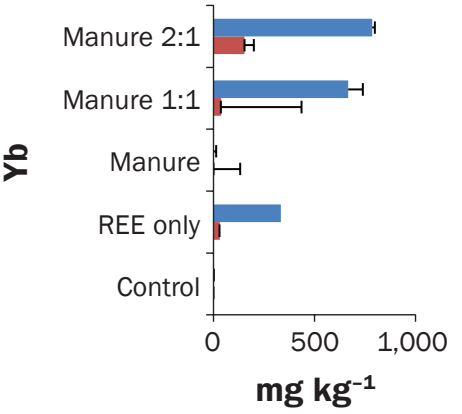

(c)

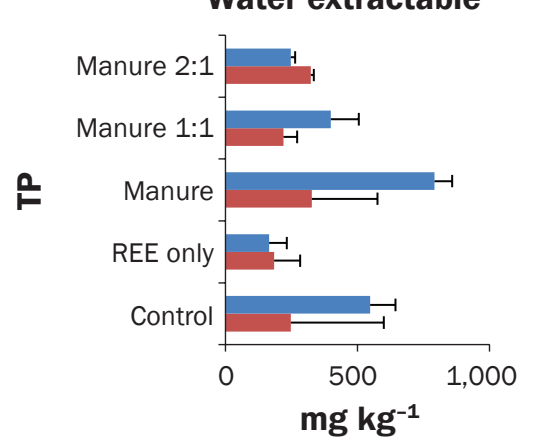

(f)

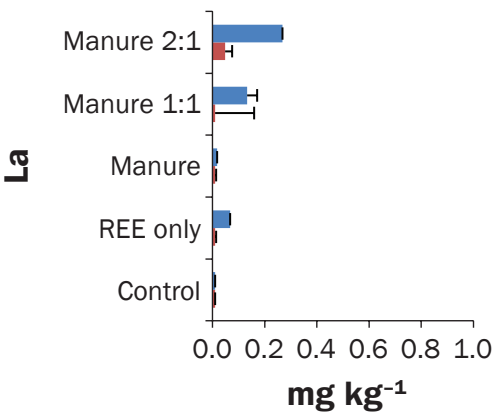

(i)

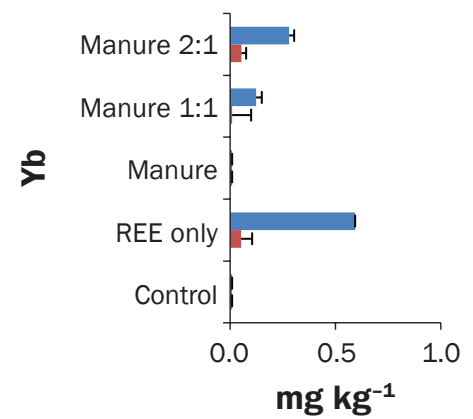

use as a chemical amendment for removal of $\mathrm{P}$ from manures. Our findings then, should serve only as a guide to the type of chemical amendment that would be ideal if its cost were not prohibitive.

The findings showed that REE-chloride application to manures greatly reduced the amount of $\mathrm{P}$ that could otherwise be readily transported through leaching to groundwater sources. However, it was much more effective in liquid dairy manures than in dry poultry litter. The reason for the differences seen between the two manures were likely due to better mixing or to dissolution of the
REE-chlorides in the liquid manures prior to being applied. While any number of reactions are possible between DP and REEs in the mixed media of manures and soils, multiple lines of evidence (in dissolved, total, and particulate $\mathrm{P}$, and in REEs) all point to the expected mechanism-the dissolution of REE-chlorides with those dissolved REEs then reacting with phosphate to form an insoluble particulate REE-phosphate saltas being the most likely explanation for the observed reductions.

The findings also indicated that the REEs exhibited little vertical transport in soils over repeated leaching events and that almost all transport to depths greater than $15 \mathrm{~cm}$ (5.9 in) was through macropores in the soils structure. Due to the extremely low concentrations of REEs found at depth (at least an order of magnitude lower than $\mathrm{P}$ ), and the much higher values of legacy $\mathrm{P}$, the concept of "labeling" the manures with REEs in order to track their progress through macropores in the soil is possible, but was not conclusively shown. Further evidence, such as detailed isolation and examination of the nature of REE chemical compounds formed when REEs and manures were mixed, would 


\section{Figure 5}

Extractable (a, b, c) total phosphorus (TP), (d, e, f) lanthanum (La), and (g, h, i) ytterbium (Yb) in Honeoye soils. REE refers to rare earth elements.

Total

(a)

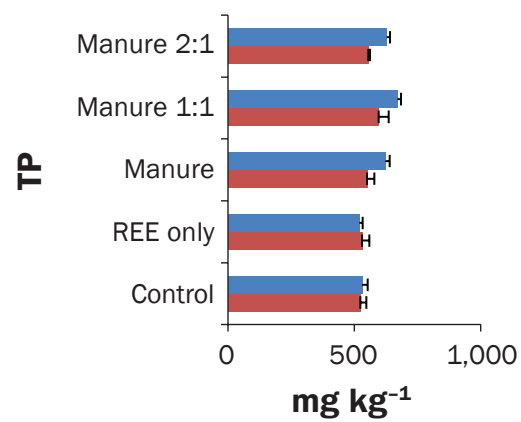

(d)

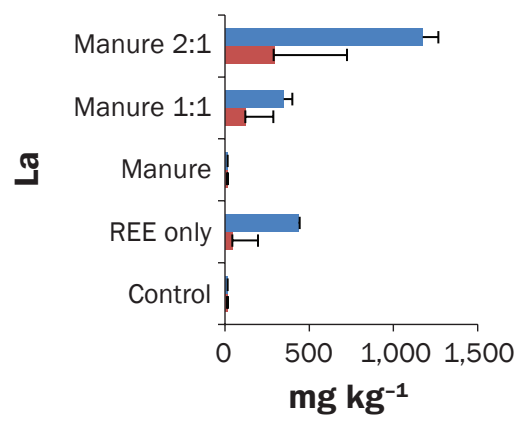

(g)

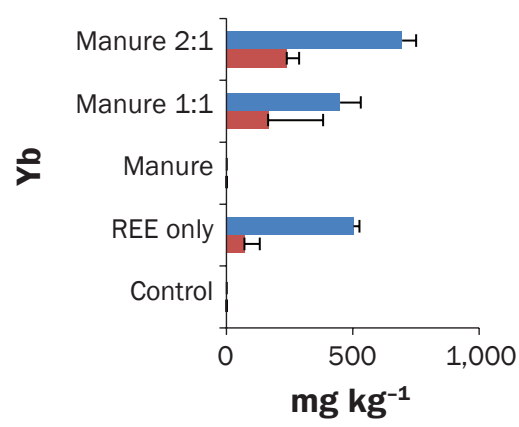

\section{Legend}

0 to $1 \mathrm{~cm}$

1 to $3 \mathrm{~cm}$ (b)

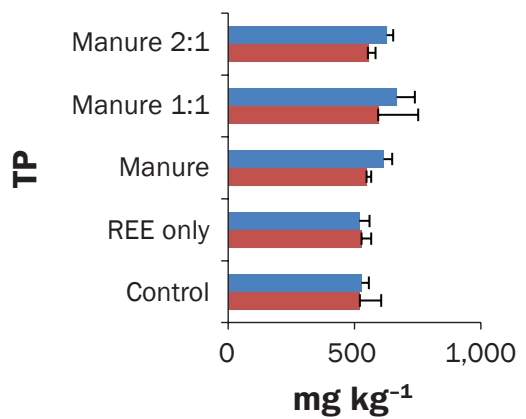

(e)

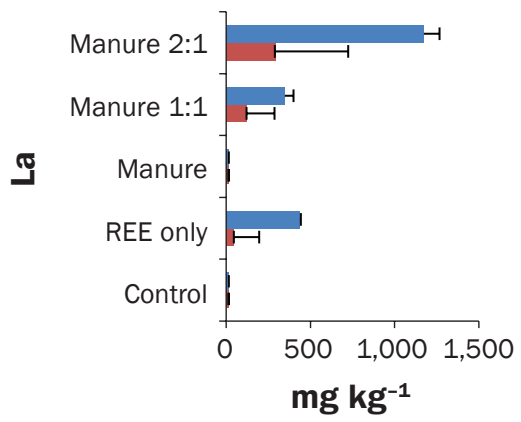

(h)

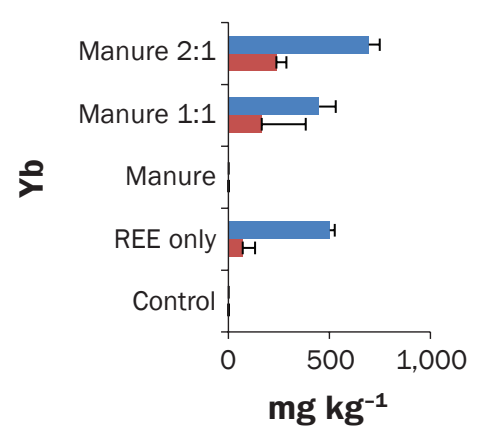

(c)

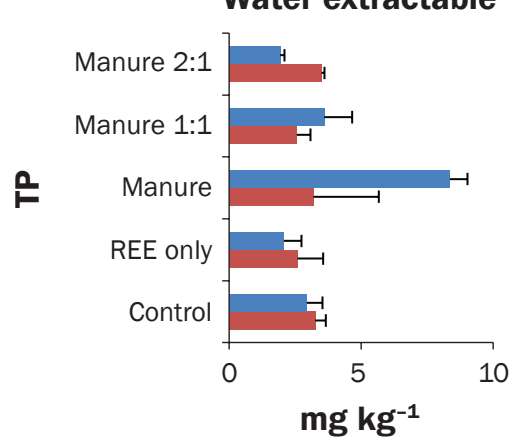

(f)

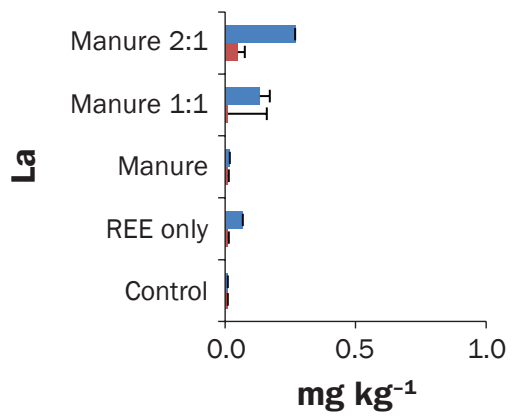

(i)

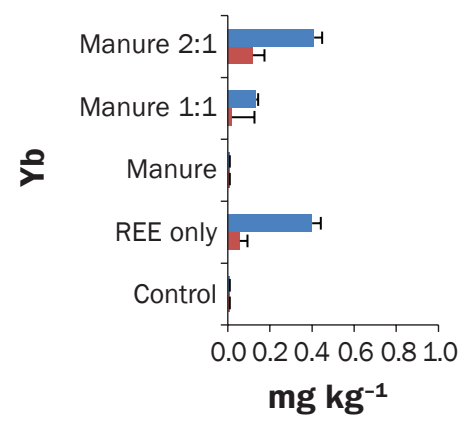

be necessary to conclusively show that the $\mathrm{P}$ had been labeled, but were beyond the scope of this study.

\section{Acknowledgements}

The authors would like to thank Don Mahan (research technician, University of Maryland- Eastern Shore, Princess Anne, Maryland), David Otto, and Michael Reiner (field technicians, USDA ARS, Klingerstown, Pennsylvania) for help in collecting soil columns. Thanks are also extended to Brianna Brighman (student intern, Pennsylvania State University, University Park, Pennsylvania) for her help in conducting the column leaching experiment, Mary-Kay Lupton (research associate, Pennsylvania State University,
University Park, Pennsylvania) for her preliminary work on soil column leaching, and to Sarah Fishel and Paul Spock (laboratory technicians, USDA ARS, University Park, Pennsylvania) for conducting laboratory experiments.

\section{Disclaimer}

USDA is an equal opportunity provider and employer. Mention of trade names or commercial products in this publication is solely for the purpose of providing specific information and does not imply recommendation or endorsement by the USDA.

\section{References}

Beegle, D.B. 2013. Soil Fertility Management. In The Agronomy Guide, 19-52. University Park, PA: Penn State College of Agricultural Sciences. http://pubs.cas. psu.edu/FreePubs/PDFs/agrs026.pdf.

Brown, M.B., and A.B. Forsythe. 1974. Robust tests for the equality of variances. Journal of the American Statistical Association 69:364-367.

Bryant, R.B., A.R. Buda, P.J.A. Kleinman, C.D. Church, L.S. Saporito, G.J. Folmar, S. Bose, and A.L. Allen. 2012. Using flue gas desulfurization gypsum to remove dissolved phosphorus from agricultural drainage waters. Journal of Environmental Quality 41:664-671.

Buda, A.R., C. Church, P.J.A. Kleinman, L.S. Saporito, and B.G. Moyer. 2010. Using rare earth elements to control 


\section{Figure 6}

Extractable (a, b, c) total phosphorus (TP), (d, e, f) lanthanum (La), and (g, h, i) ytterbium (Yb) in Metapeake soils. REE refers to rare earth elements.

Total

(a)

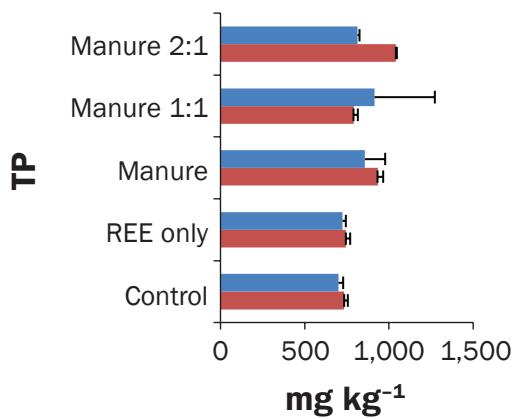

(d)

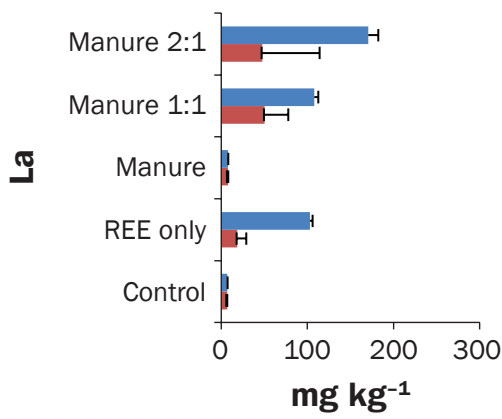

(g)

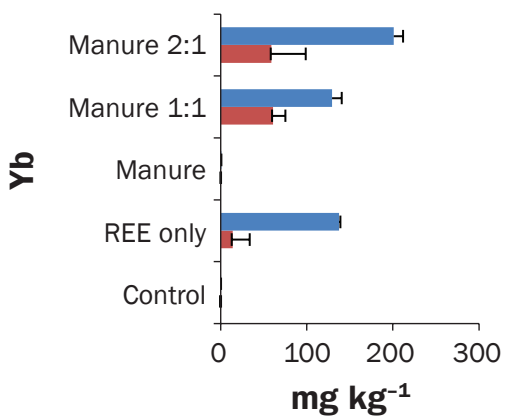

Legend

0 to $1 \mathrm{~cm}$

1 to $3 \mathrm{~cm}$ (b)

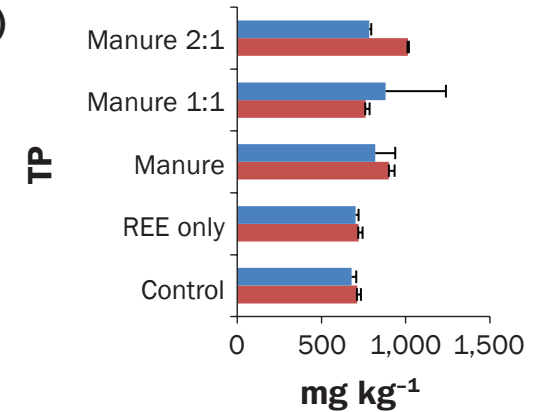

(e)

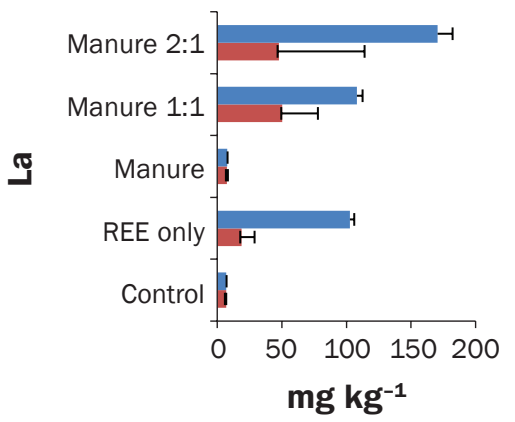

(h)

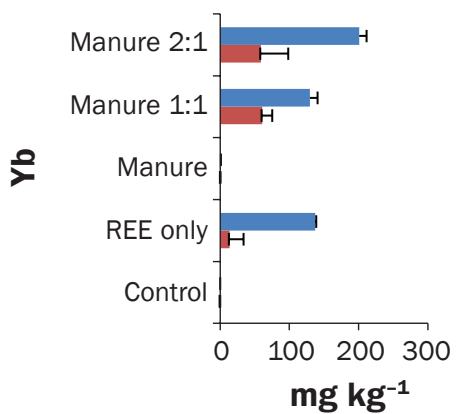

(c)

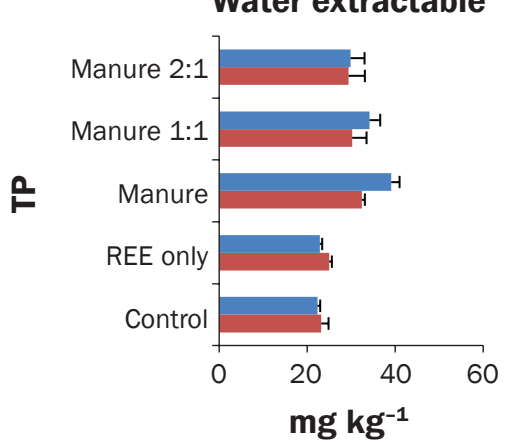

(f)

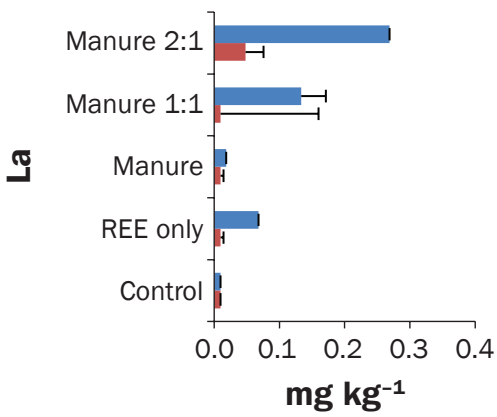

(i)

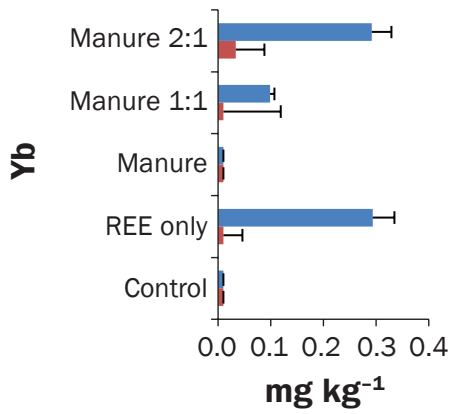

phosphorus and track manure in runoff. Journal of Environmental Quality 39:1028-1035.

Buda, A.R., G.F. Koopmans, R.B. Bryant, and W.J. Chardon. 2012. Emerging technologies for removing nonpoint phosphorus from surface water and groundwater: Introduction. Journal of Environmental Quality 41:621-627.

Chardon, W.J., J.E. Groenenberg, E.J.M. Temminghoff, and G.F. Koopmans. 2012. Use of reactive materials to bind phosphorus. Journal of Environmental Quality 41:636-646.

Church, C.D., P.J.A. Kleinman, R.B. Bryant, L.S. Saporito, and A.L.Allen. 2010. Occurrence of arsenic and phosphorus in ditch flow from litter-amended soils and barn areas. Journal of Environmental Quality 39:2080-2088.
Church, C.D., J.E. Hill, and A.L.Allen. 2011. Fate and transport of arsenic from organoarsenicals fed to poultry. In The Environmental Chemistry of Animal Manures, ed. He Zhongqi, 415-426. New York: Nova Science Publishers.

Djodjic, F., L. Bergstrom, and B. Ulen. 2002. Phosphorus losses from a structured clay soil in relation to tillage practices. Soil Use and Management 18:79-83.

Domagalski, J.L., and H.M. Johnson. 2011. Subsurface transport of orthophosphate in five agricultural watersheds, USA. Journal of Hydrology 409:157-171.

Douglas, G.B., M.S. Robb, D.N. Coad, and P.W. Ford. 2004. A review of solid phase adsorbents for the removal of phosphorus from natural and waste waters. In Phosphorus in Environmental Technologies: Principles and Applications, ed. E.Valsami-Jones, 291-320. London: International Water Association (IWA) Publishing.
Firsching, F.H., and S.N. Brune. 1991. Solubility products of the rare-earth phosphates. Journal of Chemical Engineering Data 36(1):93-95.

Frey, S.K., E. Topp, B.R. Ball, M. Edwards, N. Gottschall, M. Sunohara, E. Zoski, and D.R. Lapen. 2013. Tile drainage management influences on surface-water and groundwater quality following liquid manure application. Journal of Environmental Quality 42:881-892.

Garbarino, J.R., A.J. Bednar, D.W. Rutherford, R.S Beyer, and R.L. Wershaw. 2003. Environmental fate of roxarsone in poultry litter. I. Degradation of roxarsone during composting. Environmental Science and Technology 37:1509-14.

Geological Survey of Japan. 2005. Atlas of Eh pH diagrams: Intercomparison of thermodynamic databases. Geological Survey of Japan Open File Report Number 


\section{Figure 7}

Extractable (a, b, c) phosphorus (P), (d, e, f) lanthanum (La), and ( $g, h, i)$ ytterbium (Yb) in macropore and matrix of Hagerstown soils. REE refers to rare earth elements.

Total

(a)

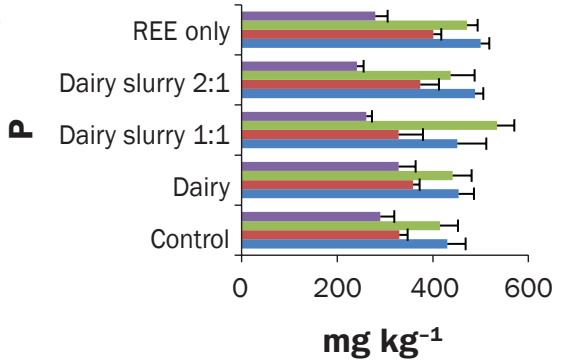

(d)

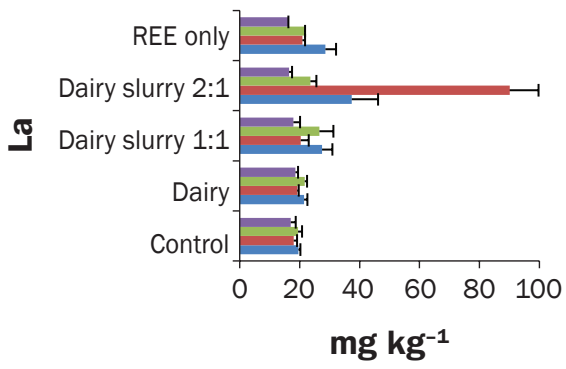

(g)

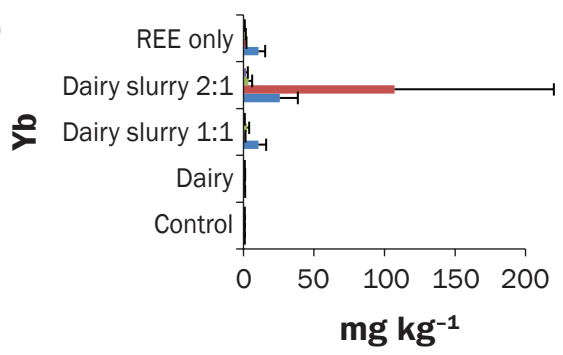

(b)

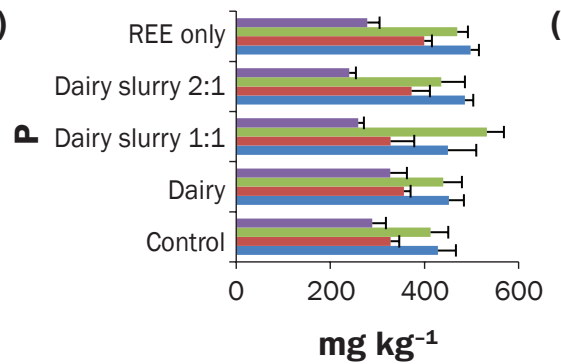

(e)

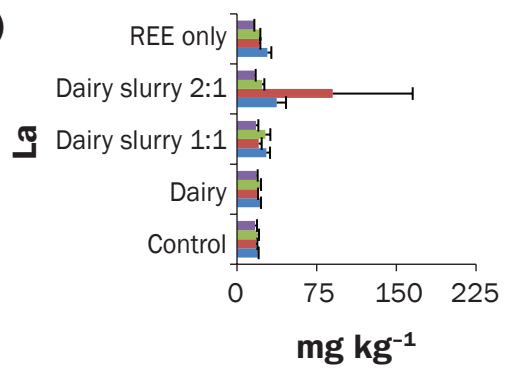

(c)

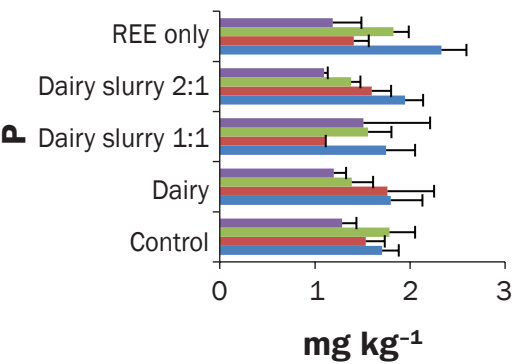

(f)

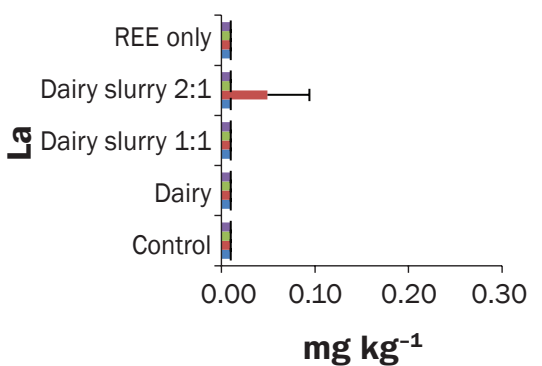

(i)

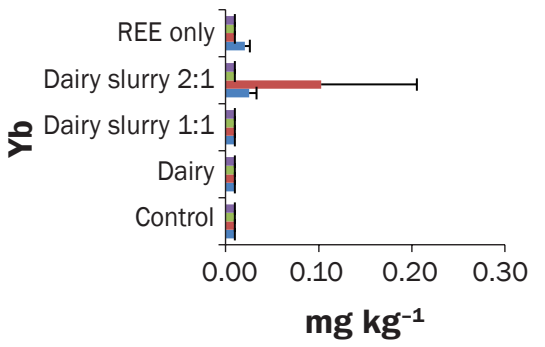

(h)

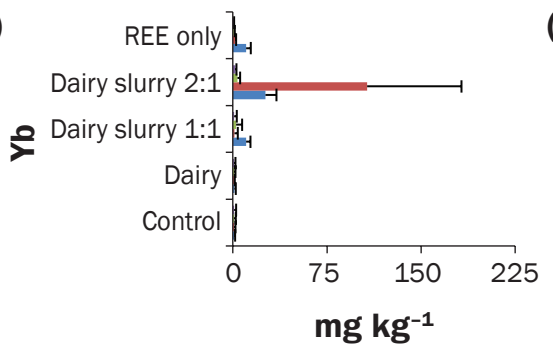

Water extractable

Legend

Matrix 30

Matrix 15

Macropore 30

Macropore 15
419. Tokyo: National Institute of Advanced Industrial Science and Technology, Research Center for Deep Geological Environments.

Han, K., P.J.A. Kleinman, L.S. Saporito, C. Church, J.M McGrath, M.S. Reiter, S.C. Tingle, A.L. Allen, L.Q. Wang, and R.B. Bryant. 2015. Phosphorus and nitrogen leaching before and after tillage and urea application. Journal of Environmental Quality 44:560-571.

Holman, I.P., M.J. Whelan, N.J.K. Howden, P.H. Bellamy, N.J. Willby, M. Rivas-Casado, and P. McConvey. 2008. Phosphorus in groundwater-An overlooked contributor to eutrophication? Hydrological Processes 22:5121-5127.

Keuls, M. 1952. The use of the "studentized range" in connection with an analysis of variance. Euphytica 1:112-122.

Kibet, L.C., A.L. Allen, C.D. Church, P.J.A. Kleinman, G.W. Feyereisen, L.S. Saporito, F. Hashem, and T.R. Way. 2013. Transport of dissolved trace elements in surface runoff and leachate from a coastal plain soil after poultry litter application. Journal of Soil and Water Conservation 68(3):212-220, doi:10.2489/jswc.68.3.212.
Kijkowska, R., and R.Z. LeGeros. 2005. Preparation and properties of lanthanide phosphates. Key Engineering Materials 284-286:79-82.

Kleinman, P.J.A., M.S. Srinivasan, A.N. Sharpley, and W.J Gburek. 2005. Phosphorus leaching through intact soil columns before and after poultry manure applications. Soil Science 170:153-166.

Kleinman, P.J.A., A.L. Allen, B.A. Needelman, A.N. Sharpley, P.A. Vadas, L.S. Saporito, G.J. Folmar, and R.B. Bryant. 2007a. Dynamics of phosphorus transfers from heavily manured coastal plain soils to drainage ditches. Journal of Soil and Water Conservation 62(4):225-235.

Kleinman, P.J.A., D. Sullivan, A. Wolfe, R. Brandt, Z. Dou, H. Elliott, J. Kovar, A. Leytem, R. Maguire, P. Moore, L. Saporito, A. Sharpley, A. Shober, T. Sims, J. Toth, G. Toor, H. Zhang, and T. Zhang. 2007b. Selection of a water extractable phosphorus test for manures and biosolids as an indicator of runoff loss potential. Journal of Environmental Quality 36:1357-1367.

Leader, J.W., E.J. Dunne, and K.R. Reddy. 2008 Phosphorus sorbing materials: Sorption dynamics and physicochemical characteristics. Journal of Environmental Quality 37:174-181.

Liang, T., W.C. Song, L.Q. Wang, P.J.A. Kleinman, and H.Y. Cao. 2010. Interactions between exogenous rare earth elements and phosphorus leaching in packed soil columns. Pedosphere 20:616-622.

Loell, M., W. Reiher, and P. Felix-Henningsen. 2011. Journal of Plant Nutrition and Soil Science 174:644-654.

Miller, M.L., J.H. Bhadha, G.A. O'Connor, J.W. Jawitz, and J. Mitchell. 2011. Aluminum water treatment residuals as permeable reactive barrier sorbents to reduce phosphorus losses. Chemosphere 83:978-983.

Mioduski, T., C. Guminski, and D. Zeng. 2008. Journal of Physical and Chemical Reference Data 37:1765-1853.

Moore, P.A., Jr., and D.M. Miller. 1994. Reducing phosphorus solubility in poultry litter with aluminum, calcium, and iron amendments. Journal of Environmental Quality 23:325-330.

Neupane, G., and R.J. Donahoe. 2013. Calcium phosphate treatment of contaminated soil for arsenic immobilization. Applied Geochemistry 28:145-154. 
Figure 8

Extractable (a, b, c) phosphorus (P), (d, e, f) lanthanum (La), and (g, h, i) ytterbium (Yb) in macropore and matrix of Honeoye soils. REE refers to rare earth elements.

Total

(a)

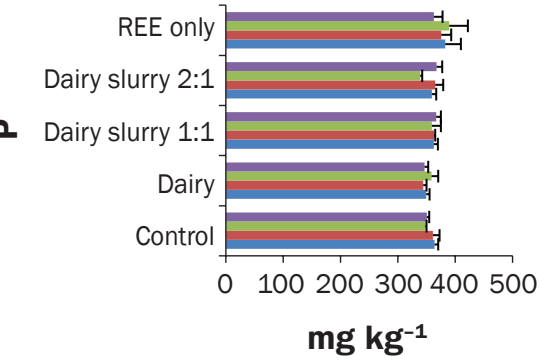

(d)

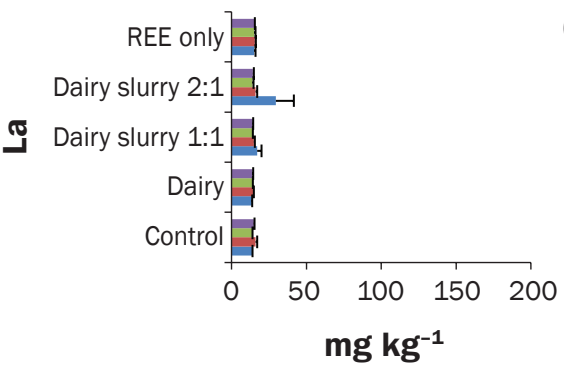

(g)

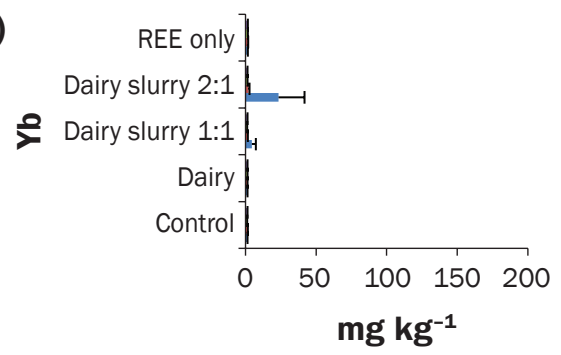

(b)

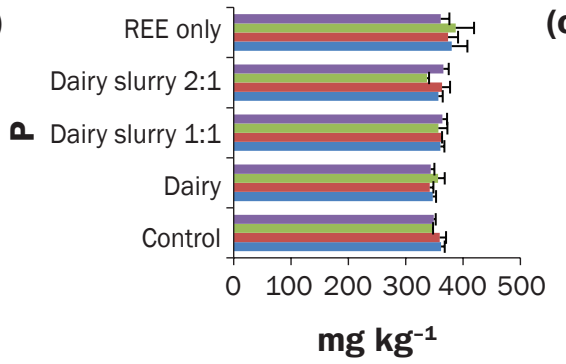

(e)

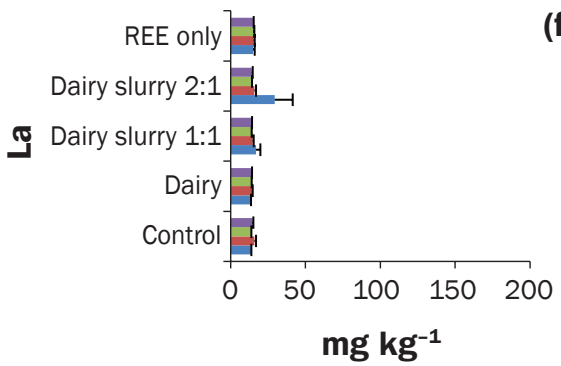

(h)

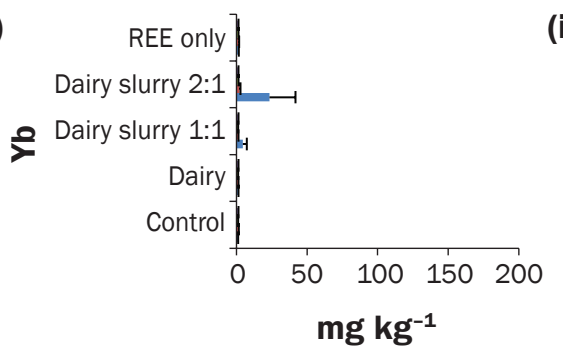

Water extractable

(c)

-

a. Dairy slurry 1:1

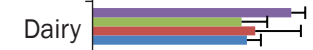

Control

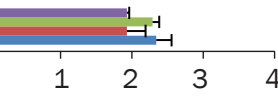

mg kg-1 (f)

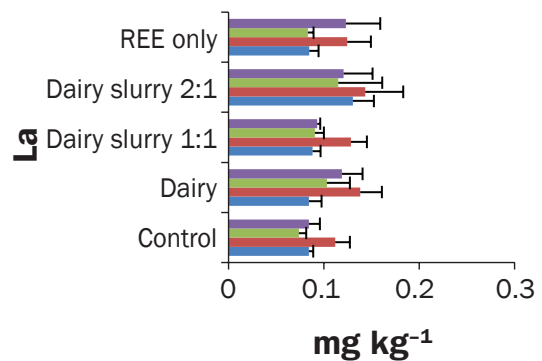

(i)

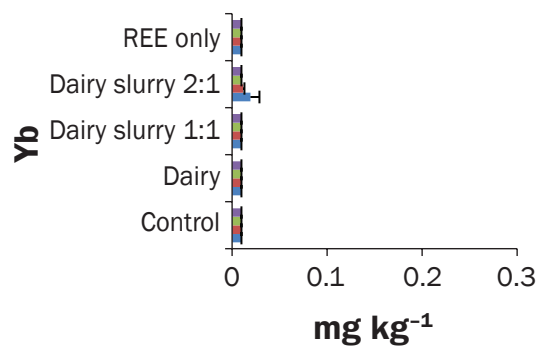

\section{Legend}

Matrix 30

Macropore 30

Matrix 15

Macropore 15

Peake, D., J.T. Sims, and D.L. Sparks. 2002. Solid state speciation of natural and alum amended poultry litter using XANES Spectroscopy. Environmental Science and Technology 36:4253-4261.

Polyakov, V.O., M.A. Nearing, and M.J. Shipitalo. 2004. Tracking sediment redistribution in a small watershed: Implications for agro-landscape evolution. Earth Surface Processes and Landforms 29:1275-1291.

Sharpley, A. N., S.C. Chapra, R. Wedepohl, J.T. Sims, T.C. Daniel, and K.R. Reddy. 1994. Managing agricultural phosphorus for protection of surface waters: Issues and options. Journal of Environmental Quality 23:437-451.

Schelde, K., L.W. de Jonge, C. Kjaergaard, M. Laegdsmand, and G.H. Rubaek. 2006. Effects of manure application and plowing on transport of colloids and phosphorus to tile drains. Vadose Zone Journal 5:445-458.

Shober, A.L., D.L. Hesterberg, J.T. Sims, and S. Gardner. 2006. Characterization of phosphorus species in biosolids and manures using XANES Spectroscopy. Journal of Environmental Quality 35:1983-1993.

Wang, L., T. Liang, P.J.A. Kleinman, and H. Cao. 2011a. An experimental study on using rare earth elements to trace phosphorus losses from nonpoint sources. Chemosphere 85:1075-1079.

Wang, L., T. Liang, Z. Chong, and C. Zhang. 2011b. Effects of soil type on leaching and runoff transport of rare earth elements and phosphorus in laboratory experiments. Environmental Science and Pollution Research 18:38-45.

Wang, L., T. Liang, W. Wang, and C. Zhang. 2012. Effects of antecedent soil moisture on losses of rare earth elements and phosphorus in runoff. Environmental Earth Science 66:2379-2385.

Welch, B.L. 1947. The generalization of 'Students' problem when several different population variances are involved. Biometrica 34:28-35.

Yoon, S., P.A. Helmke, J.E. Amonette, and W.F. Bleam. 2002. X-ray absorbtion and magnetic studies of trivalent lanthanide ions sorbed on pristine and phosphate-modified boehmite surfaces. Langmuir 18:10128-10136. 